\title{
The Research on Logistic Model and Its Application in the Association Analysis of Marxism-Leninism and Ideological and Political Education
}

\author{
Fengyan Jiang ${ }^{1}$, Wei zhao ${ }^{2}$, Shuxia $\mathrm{Wu}^{3}$ \\ ${ }^{1}$ Department of Physical Education, Hebei Institute of Physical Education, Shijiazhuang China \\ jiang_fengyan@126.com \\ ${ }^{2}$ Department of Social Sports, Hebei Institute of Physical Education, Shijiazhuang, China \\ ${ }^{3}$ Ideological and Political Teaching Department, Hebei Institute of Physical Education \\ Shijiazhuang, China
} Keywords: interdependence; ideological and political education; logistic model; equilibrium point;
stability analysis

\begin{abstract}
Using the interdependence theory of population, Logistic Model has been built in this article. After the analysis of stability, the equilibrium point cannot found. From the analysis, we can find that if the equilibrium point $A_{1}\left(N_{1}, 0\right)$ is stable, the Marxism-Leninism does not exist in the political quality education for the college students theoretically, which means that the political quality education has lost its soul and the equilibrium point $A_{1}\left(N_{1}, 0\right)$ can't be found. If the equilibrium point $A_{3}\left(0, N_{2}\right)$ is stable, the political education for college students doesn't appear in the political quality for college students, which does not conform to the Chinese condition. The guide of the Marxism-Leninism theory to the Ideological and political education determines the result of the ideological and political education. Meanwhile the effective results of the ideological and political education will also improve the Marxism-Leninism.
\end{abstract}

\section{Introduction}

Education is the foundation. Colleges and universities are the wisdom source of the development of society and economy. They also take the responsibility of cultivating the talents with good qualities. And the ideological and political education is especially important. With the development of socialist market economy, many new problems and things appear. Now the university students pay much attention to the new problems and things and their outlook on world and life ${ }^{[1][2]}$ has been greatly influenced. But the quality of the information literacy of the college students has a lot of disadvantages ${ }^{[3]}$, such as weak info awareness, different info processing abilities, which shows the necessity of the ideological and political education.

In the over 60 years since the establishment of our country, the design and reform of college political curriculum show the following disciplines. Now the design of the course has won the attentions from the central government. It designed according to the central task of the Party and the Marxism-Leninism is always the main content of the course ${ }^{[4][5]}$. Marxism is the basic guiding ideology to consolidate the Party and country and the common ideology foundation of the Chinese people. In broad sense, the Marxism includes Marxism basic theories and Marxism in China. Ideological and political education has the responsibility of teaching the university students the basic theories of Marxism. Since the foundation of China, the college political course has been reformed and the name of the course has been changed. But the basic theories of Marxism and Marxism in China are the main courses and contents of ideological and political education. ${ }^{[6]}$

\section{The association analysis of Marxism-Leninism and ideological and political education}

In college political quality education, the theories of Marxism and the ideological and political education supplement each other, which is just like two populations existing in the same natural environment depending mutually and living with each other ${ }^{[7]}$. The political quality of college students is just like the nature and Marxism and college political therefore are the two populations.

In order to increase political quality, on the basis of keeping the curriculum stable, we must regard the Marxism as the guiding ideology and improve the students' political quality and spread the 
Marxism by modifying and supplementing the teaching contents. The impact discipline of ideological and political education to the students' political quality got from Logistic Model is

$$
Y_{1}(\mathrm{t})=\gamma_{1} y_{1}\left(1-\frac{\mathrm{y}_{1}}{\mathrm{~N}_{1}}+\mathrm{b}_{1} \frac{\mathrm{y}_{2}}{\mathrm{~N}_{2}}\right)
$$

$Y_{1}(\mathrm{t})$ is the influence quantity of ideological and political education at the time $t ; \gamma_{1}$ is the update rate of the ideological and political education; $N_{1}$ is the highest requirement of the ideological and political education to the students' political quality; $b_{1}$ is the impact of Marxism to the ideological and political education reforms concerning the present Chinese condition; $N_{2}$ is the highest requirement of Marxism theory to the college students' political quality.

The impact of Ideological and political education to the students' political quality is influenced by the teaching materials and the contents of the materials are influenced by the Chinese conditions. Similarly, when the students receive the political education, the Marxism can be improved. The relation between the two aspects is mutual improvement, which can be shown in Fig. 1.

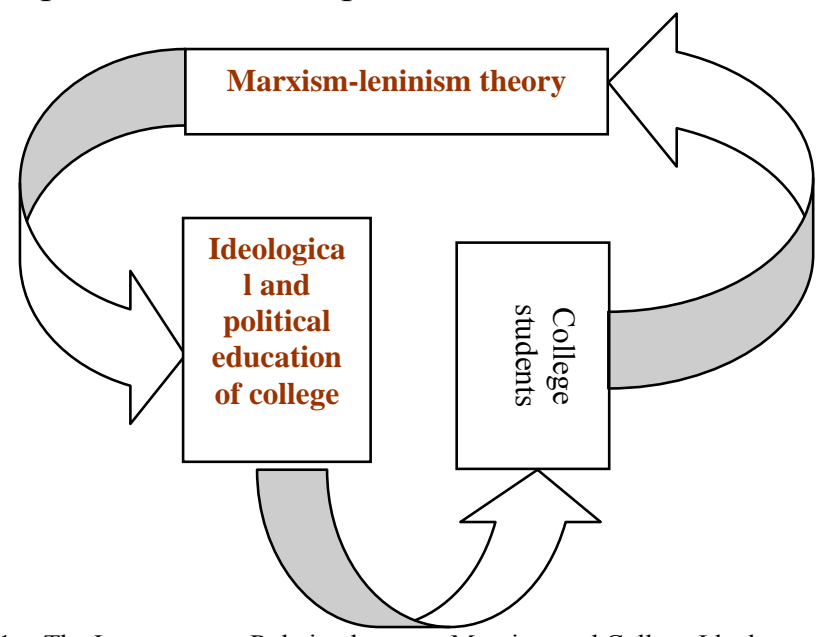

Figure 1. The Improvement Relation between Marxism and College Ideology and Politics

The Marxism-Leninism is the scientific theory testified by the practice. It is also the guiding ideology of the constructions of socialism with Chinese characters, which is beneficial to the conformation of right concepts of world, life and values. Without the guidance of the MarxismLeninism, there is no foundation for the ideological and political education. Suppose $\gamma_{2}$ represents the negative impact rate of Marxism-Leninism to the ideological and political education, then the following linear equation can be found

$$
Y_{2}(\mathrm{t})=\gamma_{2} y_{\underline{z}}
$$

The guidance of Marxism-Leninism theory to the ideological and political education can directly determine the effect of the education. Using the theory of population mutualism, the function of Marxism-Leninism theory and ideological and political education is as below,

$$
X_{2}(\mathrm{t})=\gamma_{2} y_{2}\left(\mathrm{~b}_{2} \frac{\mathrm{y}_{1}}{\mathrm{~N}_{1}}-1\right)
$$

Apparently, when $\frac{b_{2} y_{1}}{N_{1}}>1$, the ideological and political education benefits the improvement of the students quality, which shows that the Marxism-Leninism and ideological and political education are supplementing to the students quality. It can be shown in formula (4)

$$
Y_{2}(\mathrm{t})=\gamma_{2} y_{2}\left(-1+\mathrm{b}_{2} \frac{\mathrm{y}_{1}}{\mathrm{~N}_{1}}-\frac{\mathrm{y}_{2}}{\mathrm{~N}_{2}}\right)
$$

In improving the college students' qualities, the above equations construct the math model of interdependence between the Marxism-Leninism and ideological and political education. In order to make the theory develop, we will study the development trends of the two aspects in a long term by analyzing the equilibrium point stability.

3 The analysis of the stability of the college students political quality 
According to formulas (1) and (4), solve the algebra equations

$$
\left\{\begin{array}{l}
\gamma_{1} y_{1}\left(1-\frac{\mathrm{y}_{1}}{\mathrm{~N}_{1}}+\mathrm{b}_{1} \frac{\mathrm{y}_{2}}{\mathrm{~N}_{2}}\right)=0 \\
\gamma_{2} y_{2}\left(-1+\mathrm{b}_{2} \frac{\mathrm{y}_{1}}{\mathrm{~N}_{1}}-\frac{\mathrm{y}_{2}}{\mathrm{~N}_{2}}\right)=0
\end{array}\right.
$$

Then we get the equilibrium point shown as below,

$$
A_{1}\left(N_{1}, 0\right), \quad A_{2}\left(\frac{N_{1}\left(1-b_{1}\right)}{1-b_{1} b_{2}}, \frac{N_{2}\left(1-b_{2}\right)}{1-b_{1} b_{2}}\right), \quad A_{3}\left(0, N_{2}\right), \quad A_{4}(0,0)
$$

According to the math knowledge ${ }^{[9]}$, to get the stability of the equilibrium point is to get the result of partial derivative of independent variables $y_{1}$ and $y_{2}$ in the functions of (1) and (4). Then the corresponding coefficient matrix $B$ is

$$
\begin{aligned}
B & =\left[\begin{array}{ll}
Y_{1 y_{1}} & Y_{1 y_{2}} \\
Y_{2 y_{1}} & Y_{2 y_{2}}
\end{array}\right] \\
& =\left[\begin{array}{cc}
\gamma_{1}\left(1-\frac{2 y_{1}}{N_{1}}-\frac{b_{1} y_{2}}{N_{2}}\right) & -\frac{\gamma_{1} b_{1} x_{1}}{N_{2}} \\
-\frac{\gamma_{2} b_{2} y_{2}}{N_{1}} & \gamma_{2}\left(1-\frac{b_{2} y_{1}}{N_{1}}-\frac{2 y_{2}}{N_{2}}\right)
\end{array}\right]
\end{aligned}
$$

And the coefficient of the secular equation is

$$
\begin{gathered}
p=-\gamma_{1}\left(1-\frac{2 \mathrm{y}_{1}}{\mathrm{~N}_{1}}-\frac{\mathrm{b}_{1} y_{2}}{\mathrm{~N}_{2}}\right)-\gamma_{2}\left(1-\frac{\mathrm{b}_{2} y_{1}}{N_{1}}-\frac{2 \mathrm{y}_{2}}{\mathrm{~N}_{2}}\right) \\
q=\operatorname{det} A
\end{gathered}
$$

The results of $p$ and $q$ the four equilibrium points corresponding to and the condition of stability are listed in Table 1.

\begin{tabular}{|l|l|l|l|}
\hline \multicolumn{1}{|c|}{ TABLE I. } & \multicolumn{1}{c|}{ THE EQUILIBRIUM POINT AND STABILITY } \\
\hline$A_{1}\left(N_{1}, 0\right)$ & \multicolumn{1}{c|}{$p$} & \multicolumn{1}{c|}{$\begin{array}{c}\text { Conditions of } \\
\text { Stability }\end{array}$} \\
\hline$A_{2}\left(\frac{N_{1}\left(1-b_{1}\right)}{1-b_{1} b_{2}}, \frac{N_{2}\left(1-b_{2}\right)}{1-b_{1} b_{2}}\right)$ & $\frac{\gamma_{1}\left(1-b_{1}\right)+\gamma_{2}\left(b_{2}-1\right)}{1-b_{1} b_{2}}$ & $\frac{\gamma_{1} \gamma_{2}\left(1-b_{1}\right)\left(b_{2}-1\right)}{1-b_{1} b_{2}}$ & $b<1, b_{2}>1, h b_{2}<1$ \\
\hline$A_{3}\left(0, N_{2}\right)$ & $\gamma_{2}-\gamma_{1}\left(1-b_{2}\right)$ & $-\gamma_{1} \gamma_{2}\left(b_{1}-1\right)$ & Not Stable \\
\hline$A_{4}(0,0)$ & $-\gamma_{1}+\gamma_{2}$ & $-\gamma_{1} \gamma_{2}$ & Not Stable \\
\hline
\end{tabular}

If the equilibrium point $A_{1}\left(N_{1}, 0\right)$ is stable, the Marxism-Leninism does not exist in the political quality education for the college students theoretically, which means that the political quality education has lost its soul and the equilibrium point $A_{1}\left(N_{1}, 0\right)$ can't be found. If the equilibrium point $A_{3}\left(0, N_{2}\right)$ is stable, the political education for college students doesn't appear in the political quality for college students, which does not conform to the Chinese condition. Similarly, the equilibrium point $A_{4}(0,0)$ can not be found

From the table above, when $A_{2}$ is stable, $b_{1}<1, b_{2}>1, b_{1} b_{2}<1$, and the phase rail line equation is

$$
1-\frac{y_{1}}{N_{1}}+b_{1} \frac{y_{2}}{N_{2}}=0 \quad \text { (6) }-1+b_{2} \frac{y_{1}}{N_{1}}-\frac{y_{2}}{N_{2}}=0
$$

And the schematic diagram is can be shown in Fig. 2. 
The tendency of the arrowhead illustrates that the stable equilibrium point is $A_{2}$, which means the Marxism-Leninism theory supplement the ideological and political education and the college students' quality can be improved constantly.

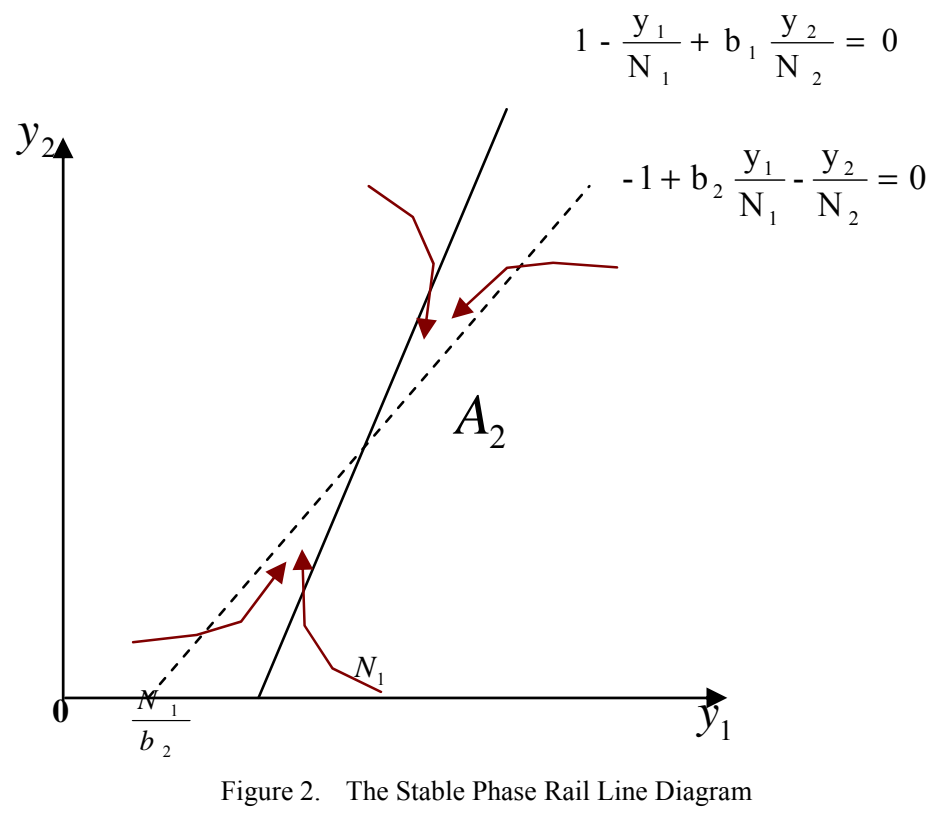

\section{Conclusions}

This article, through analyzing the impact of theory of Marxism-Leninism and ideological and political education to the students' political quality by using Logistic model, shows that MarxismLeninism and the ideological and political education are indispensable to each other. In order to improve the students' political quality, the Marxism-Leninism theory should be applied in the ideological and political education and the Marxism-Leninism can also be improved as well.

\section{References}

[1] Liu Yanxin, The Significance of Info Quality Education in College Ideological and Political Work [J], Academic Exchange, 2012 (4) : 197-199.

[2] Ai Lin, The Innovation Research of College Ideological and Political Education [J], Chuzhou Vocational and Technical College, 2010,9 (4) : 52-54.

[3] Yan Peng, Key Points of Present College Students Ideological and Political Education [J], Industry and Technology Forum, 2011,10 (14) :157-158.

[4] Gao Zhengli, Some Problems of Our College Ideological and Political Theory education [J], Scientific Socialism, 2007 (6) : 97-100.

[5] Shi Songhua, Problems and Strategies of College Ideological and Political Education [J], Moral Education Corner, 2007 (1) : 50-51.

[6] Cao Wenze, Enhancing the Timeliness and the Infectivity of College Ideological and Political Education [J], Beijing Education, 2011.

[7] http://wenku.baidu.com/view/71fbe6c15fbfc77da269b11e.html

[8] Wang Yong, The Solution of Logistic Population Model [J], Harbin University of Commerce Journal (Natural Science Edition), 2006.

[9] Wang Jichua \& Guo Zhigang, The Method and Application of Logistic Regression Model [M], Beijing, Higher Education Press, 2001 